\title{
Association of Genetic Polymorphisms in STAT 3, STAT $5 b$ and GWAS Identified PTPN22 Gene with Rheumatic Heart Disease
}

\author{
Usha Gupta ${ }^{1 *}$, Avshesh Mishra', Saurabh S. Rathore ${ }^{1}$, Snober S Mir ${ }^{2}$, SK Agarwal ${ }^{3}$, Naveen Garg ${ }^{4}$, Balraj Mittal ${ }^{1}$ \\ From International Conference on Human Genetics and 39th Annual Meeting of the Indian Society of \\ Human Genetics (ISHG) \\ Ahmadabad, India. 23-25 January 2013
}

\section{Background}

Rheumatic heart disease (RHD) is an inflammatory, autoimmune disease, occurring as a consequence of group A streptococcal infection complicated by rheumatic fever (RF). Cytokines are important mediators of inflammatory and immune responses. JAK-STATs have been demonstrated to be critical elements in signaling by certain families of cytokines. GWAS has identified PTPN22 SNPs as non-HLA genetic variants to be associated with susceptibility to autoimmune diseases. Based on these, we looked for association of genetic variants of STAT 3, STAT 5B and GWAs identified PTPN22 with RHD in North Indian population.

\section{Methods and results}

This case-control study included 400 RHD patients and 200 controls. The polymorphisms were identified using RFLP/Taqman probes. Statistical analysis was performed by using SPSS. We observed that STAT3 CG and GG genotypes were significantly associated with RHD ( $\mathrm{p}=0.024$ \& $\mathrm{p}=0.027$ respectively), STAT5b CT\&TT genotypes were significantly associated with RHD ( $=0.001$ \& $\mathrm{p}=0.002$ respectively) while both the SNPs of PTPN22 gene did not show any association with RHD. Further categorization of RHD patients into mitral valve disease (MVD) and combined valve disease (CVD) subgroups revealed that STAT3 CG\&GG genotypes were associated with MVD and STAT5 $b$ CT\&TT genotypes were also associated with both MVD\&CVD.
${ }^{1}$ Department of Genetics, Sanjay Gandhi Postgraduate Institute of Medical Sciences (SGPGIMS), Lucknow, UP, India

Full list of author information is available at the end of the article

\section{Conclusions}

STAT3 \& STAT5b gene polymorphisms may play an important role in the pathogenesis of RHD but GWAS identified PTPN22 SNPs may not be associated with susceptibility of RHD.

\section{Authors' details}

'Department of Genetics, Sanjay Gandhi Postgraduate Institute of Medical Sciences (SGPGIMS), Lucknow, UP, India. ${ }^{2}$ Department of Biotechnology, Integral University, Lucknow, UP, India. ${ }^{3}$ Department of Cardiovascular and Thoracic Surgery, Sanjay Gandhi Postgraduate Institute of Medical Sciences (SGPGIMS), Lucknow, UP, India. ${ }^{4}$ Department of Cardiology, Sanjay Gandhi Postgraduate Institute of Medical Sciences (SGPGIMS), Lucknow, UP, India.

Published: 21 January 2014

doi:10.1186/1755-8166-7-S1-P110

Cite this article as: Gupta et al: Association of Genetic Polymorphisms in STAT 3, STAT 5b and GWAS Identified PTPN22 Gene with Rheumatic Heart Disease. Molecular Cytogenetics 2014 7(Suppl 1):P110.

Submit your next manuscript to BioMed Central and take full advantage of:

- Convenient online submission

- Thorough peer review

- No space constraints or color figure charges

- Immediate publication on acceptance

- Inclusion in PubMed, CAS, Scopus and Google Scholar

- Research which is freely available for redistribution 